\title{
Clarifying the Effective Factors of Hidden Curriculum of Schools on Establishment of the Aims of Religious Education of Elementary School Students (Case Study of Ahvaz City)
}

\author{
Gholam Reza Zamanzadeh $^{1}$, Faezeh Nateghi ${ }^{2} \&$ Mohammad Seifi $^{2}$ \\ ${ }^{1}$ PH.D student, Islamic Azad University of Arak, Arak, Iran \\ ${ }^{2}$ Assistant Professor Department of Curriculum Sciences, Islamic Azad University of Arak, Arak, Iran \\ Correspondence: Faezeh Nateghi, Department of curriculum, Arak Branch, Islamic Azad University, Arak, Iran. \\ E-mail: F-nateghi@iau-arak.ac.ir
}

Received: May 17, 2016

Accepted: June 24, 2016

Online Published: October 20, 2016

doi:10.5539/mas.v11n1p124

URL: http://dx.doi.org/10.5539/mas.v11n1p124

\begin{abstract}
Current research aims to clarify the effective factors of hidden curriculum of schools o the establishment of the general goals of religious education in elementary period.

This research is practical in regard to classification of the researches on the base of purpose and approaches the issue in phenomenological manner.

Statistical population of the research includes all the principals, teachers and boy students of fifth and sixth grades of elementary schools in Ahvaz city and the samples of the research are selected through purposive sampling.

Data are gathered through unstructured interview conducted by means of open answer questions and have been continued as much as saturation of the data.

Grounded theory procedure or theory derived from data is used to analyze the data and to achieve intended model (theory) of the research and it includes four stages: 1-Coding 2-conceptualizing 3-Categorizing 4-Compiling the theory (model) of findings : In the next stage, 15 concepts of these codes are extracted and in the third stage, the mentioned concepts are organized in form of 5 categories(factor) : cognitive environment , social environment, physical environment, administrative environment, religious environment, and in the last stage, research theory (model) is formed on the base of discovered categories
\end{abstract}

Keywords: hidden curriculum, religious education, elementary education period

\section{Introduction}

Education is among the common concerns of human societies. Countries and nations define their educational goals on the base of their own mindset and political and philosophical school and this leads to a difference in style and procedure and goals. (Hajji Karim Nazari, 2009)

School is the main base of education as one of the most important instructive, educational and social institutes .The kind of school instruction has a particular effect on the social life of one nation .No instructive institution, even in the most descriptive developmental and political definitions and interpretations, isn't separated from the goals and missions and social and cultural backgrounds of its own society. (Khaniki, 2002)

Undoubtedly, achieving the goals of educational system in regard to religious instruction requires the exact and proper application of all tools and equipment's. In recent years, curriculum has always been one of the most important tools in achieving the goals of educational systems in different countries .Researchers findings acknowledge the reality that unlike the common assumption, curriculum as a field of specializations isn't confined to a collection of predetermined experiences and learnings or official explicit curriculum. There are other factors that, as well as official and explicit curriculum, affect the intellectual, value and behavioral structure of the students. These factors are so called the unintended curriculum or hidden curriculum.

\section{Literature Review}

Phillip Jackson (1968) is generally acknowledged as the originator of the term hidden curriculum in his book 
Life in Classrooms. He argued that the hidden curriculum emphasized specific skills: learning to wait quietly, exercising restraint, trying, completing work, keeping busy, cooperating, showing allegiance to both teachers and peers, being neat and punctual, and con- ducting oneself courteously (Jackson 1968, pp. 10-33).

Different perspectives on the hidden curriculum have been articulated over the past 48 years.

Robert Dreeben (1967) argued that the structure of family life alone could not adequately prepare children for the adult world. He examined the norms of school culture and concluded they taught students to "form transient social relationships, submerge much of their personal identity, and accept the legitimacy of categorical treatment" \{Dreeben 1968, p. 147).

Henry Giroux (2001) identifies hidden curriculum as what is being taught and how one learns in the school as he also indicates that schools not only provides instruction but also more such as norms and principles experienced by students throughout their education life ( Fulya Damla Kentli,2009, 84).

Michael Apple (2004) describes hidden curriculum as those attitudes, values, and beliefs that conveyed to students as part of the overall school culture but are not explicitly stated in the curriculum document (Michael Apple, 2004, p. 15).

Dickerson (2007) "The hidden curriculum consists of those things pupils learn through the experience of attending school rather than the stated educational objectives of such institutions" (Dickerson, 2007, p. 14).

Joanna Konieczka (2013) argued that the hidden curriculum as a socialization of schooling can be identified by the social interactions within an environment. Thus, it is in process at all times, and serves to transmit tacit messages to students about values, attitudes and principles. Hidden curriculum can reveal through an evaluation of the environment and the unexpected, unintentional interactions between teachers and students which revealed critical pedagogy (Joanna Konieczka, 2013, pp. 250-251).

Researchers consider different factors involved in the production of the hidden curriculum. Many of the researchers focused on social aspects of hidden curriculum such as Jackson, 1968; Ausbrooks, 2000; Myles and Andreon, 2001; Fitzroy, 2007; Chikeung, 2008; Dogany, 2002; Gobergolia, Gobble and Cawth, 2012; Guskey, 2012. Some other researchers concentrated on cognitive side of hidden curriculum on the contents and illustrations of the subject matter. They believed that sometimes the contents and illustrations of the subject matter have hidden and implied messages, which sometimes these messages are against the aims, of formal curriculum, such as stereotype encounters, racism, and sexual discrimination (Margolis, 2000; BergenheneGouwen, 2009; Redish, 2009; Stephen Son, 2009; ShurifahThuraiy, 2010). Some other researcher such as Smith and Montgomery 2008, which had focused on cognitive aspect of hidden curriculum, showed that schools do not give equal attention to different subjects. In their opinion subjects such as Mathematics, Biology and Technology have more importance. They had given more time to these subjects in their curriculum. Teachers and students give special importance to these subjects and they do not consider the others as important. Another group of researcher studied the physical aspects of hidden curriculum such as Margolis, 2001; Dexie, 2003; Weber, 2009; Ferriter, 2009. The results of their research showed those beautiful, well decorated classrooms, with good lightening and enough physical equipment's, for teaching is factors of academic achievement.

Islamic Republic of Iran believes that Islam religion is a plan for (( pure life )) in this world and salvation in that world, therefore, it has adopted a particular structure for governing the society and embrace the religious education as the most basic responsibility and organize all economic, social and cultural programs in this manner.(Ministry of Education , 2006 )

Since elementary period is the most important educational period in all education systems of the world and personality and multilateral growth of person is more formed in this period, sensitivity of this period is more than the others. (Safi, 2004)

According to the twenty years outlook document of Islamic Republic of Iran, elementary period is considered as the basic part of public and official education system of this country. Based on this outlook, elementary schools are also considered the main origin of achieving high goals of public and official education system of Iran. (Ministry of Education, 2011)

The general goals of religious education of elementary period in Iran are accumulated under the three scopes of: cognitive (knowledge and information), sentimental (tendencies and emotions) and functional (behavior and action). (Ministry of Education, 2006)

Despite emphases done in the upper documents of Iran about outstanding position of religious education, the authorities have not paid enough attention to the effect of hidden curriculum. This is while the students during 
their own education are always in a close communication with the elements of this curriculum. Identifying and analyzing hidden curriculum can be used by the authorities of education as a educational tool. (Bayanfar \& Maleki, 2011)

Today, in Iran, people in charge and the authorities pay more attention to the official and intended curriculum and an important dimension of curriculum, namely hidden curriculum, affecting severely the major part of goals and content of education system of Iran is overlooked. (Fallah, Vahid, Barimany \& Niazazar, 2012)

We may acknowledge the saying by John Dewey (Dewey, J) about the education of our country that the greatest fallacy of education is that people in charge of education think that children learn what they present at schools. (Mehrmohammadi, 2001)

In the current research, given the pivotal position of religious education in education system of Iran on one hand and according to the importance of elementary period as primary origin of movement toward achieving the goals of religious education of students in Iran on the other hand, it is attempted to clarify the effect of elements or components of hidden curriculum on achieving the general goals of religious education in elementary period while designing a model for decreasing the negative effects and consequences and increasing the positive effects and consequences of this kind of curriculum on achieving the goals of religious education in the mentioned period.

\section{Methodology}

The current research, based on the purpose, is classified as practical that approaches the issue in a phenomenological manner and grounded theory procedure is used to analyze the data obtained from interview with samples of the research.

The statistical population of the research includes all the elementary schools pertaining to boys in four districts of Ahvaz city in school year 94-95 that two districts of the mentioned districts were selected through cluster random procedure in two stages and then, 5 schools were selected out of each district and the samples of the research were selected through purposive sampling from among principals, teachers and students of these schools.

In this research, the tool has been unstructured interview by means of open answer questions for gathering the required data. Each interview took at most 70 and at least 40 minutes. All the interviews were conducted in one of the decent work rooms allocated to this affair in association with the management.

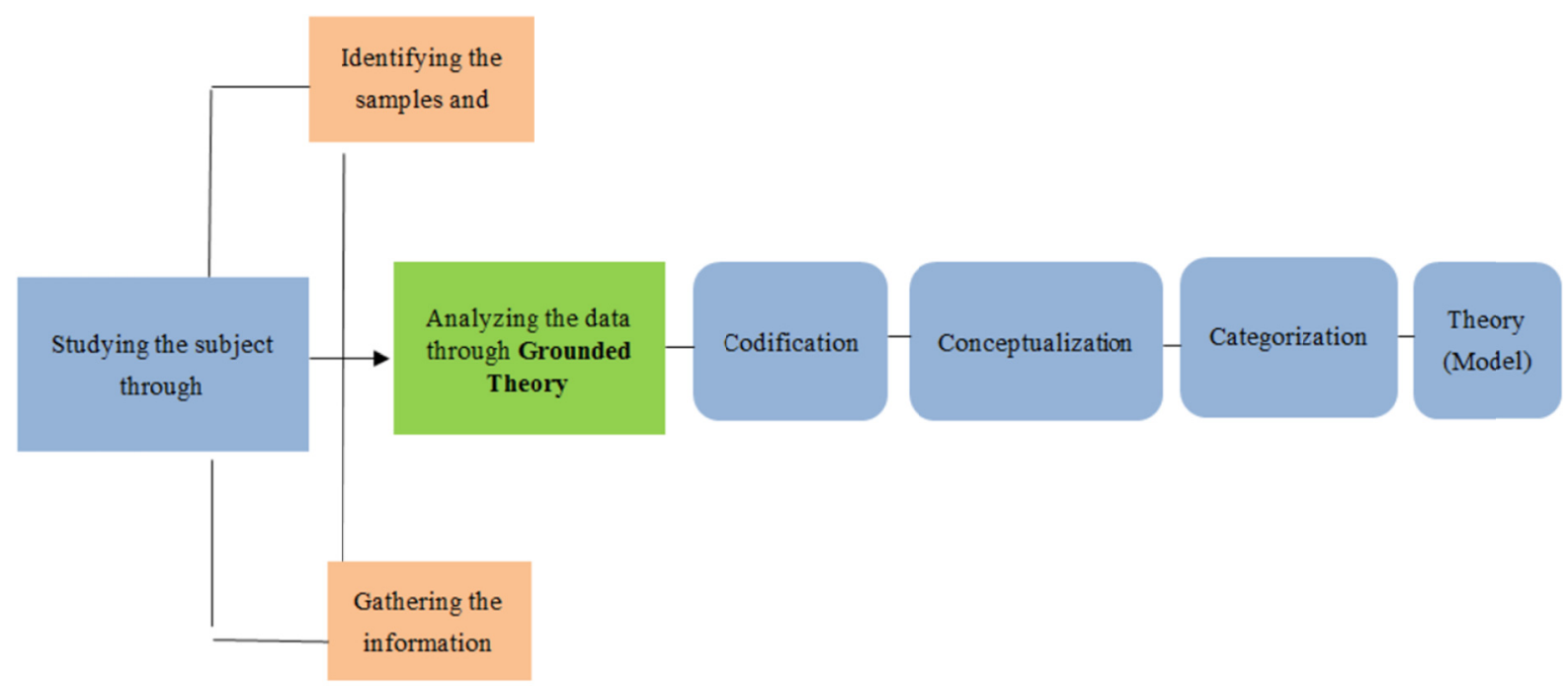

Figure 1. Progress diagram ended up in field model of the research

\section{Findings of the Research}

Gathering the data through interview with samples ended up in saturation of the data and not receiving any kind of new information after interviewing with the thirty fifth person. Then, the gathered data were analyzed through grounded theory procedure or theory derived from data in 4 stages. In the first stage, while investigating exactly 
the raw data obtained from interviews, the answers were extracted in the form of short phrases and a joint code was determined to raw data almost similar to each other and 86 codes were finally obtained .In the second stage ,conceptualization was conducted, in a way that some joint codes pointing to one concept were formed in one concept. 15 concepts were extracted at the end of this stage .In the third stage, classification was conducted and some close concepts were categorized in one form .At the end of this stage, concepts were organized in the form of 5 categories(elements) : cognitive environment, social environment, administrative environment, religious environment, and at the last stage ,based on the discovered categories ,theory (model) of the research was formed.

Demographic information of research statistical population samples:

Table 1. Frequency distribution of interviewees according to position

\begin{tabular}{llll}
\hline Position & Frequency & Frequency percentage & Cumulative frequency percentage \\
\hline Principal & 5 & $\% 14.29$ & $\% 14.29$ \\
Teacher & 10 & $\% 28057$ & $\% 42.86$ \\
Student & 20 & $\% 57.14$ & $\% 100$ \\
Total & 35 & $\% 100$ & $\% 100$ \\
\hline
\end{tabular}

Table 2. Frequency distribution of interviewees according to gender

\begin{tabular}{llll}
\hline Gender & Frequency & Frequency percentage & Cumulative frequency percentage \\
\hline Man & 32 & $91.43 \%$ & $91.43 \%$ \\
Woman & 3 & $8.57 \%$ & $100 \%$ \\
Total & 35 & $100 \%$ & $100 \%$ \\
\hline
\end{tabular}

Table 3. Frequency distribution of principals and teachers being interviewed according to academic degree

\begin{tabular}{lll}
\hline Academic degree & Frequency & Percentage \\
\hline Junior college diploma & 2 persons & $13 \%$ \\
B.A & 9 persons & $60 \%$ \\
M.A & 4 persons & $27 \%$ \\
Total & 15 persons & $100 \%$ \\
\hline
\end{tabular}

Table 4. Frequency distribution of the students being interviewed according to their school grade

\begin{tabular}{llll}
\hline School grade & Frequency & Frequency percentage & Cumulative frequency \\
\hline Fifth grade & 11 & $55 \%$ & $55 \%$ \\
Sixth grade & 9 & $45 \%$ & $100 \%$ \\
total & 20 & $100 \%$ & $100 \%$ \\
\hline
\end{tabular}

According to results inserted in table 5, the concept of "content of the lesson" is obtained as a result of merging codes in rows 1 to 7, the concept of "teaching method" as a result of merging codes in rows 8-15 and the concept of "evaluation procedure" as a result of merging codes 16-20. This three concepts together formed "cognitive environment" category or element as one of the effective factors of curriculum on achieving the goals of religious education at elementary schools .Findings of the research about introduction of the cognitive environment as one of the effective elements of hidden curriculum at schools are similar to the standpoints of some of the pundits such as Stephenson (2009), Redish (2009) and Bergenhenegouwen (2009) that concentrated on the content-cognitive dimension of this curriculum . They believe that the content of textbooks are hidden subjects and purposes that are not also similar to the goals of the explicit curriculum.

Table 5. Information of extractive structure of cognitive environment category of hidden curriculum

\begin{tabular}{clcc}
\hline Row & \multicolumn{1}{c}{ Joint code } & Concepts & Category \\
\hline 1 & Comprehensibility of content of lesson & Content of lesson & \\
2 & Without accumulation of subjects & (codes 1 to 7) & \\
3 & Without multiplicity subjects & & \\
\hline
\end{tabular}




\begin{tabular}{|c|c|c|c|}
\hline 4 & Correlation of the content with the main issues of society & & \\
\hline 5 & Noticeability and tangibility of content of lessons & & \\
\hline 6 & Attractiveness of content & & \\
\hline 7 & $\begin{array}{l}\text { Conformity among general goals and selective content of } \\
\text { lesson }\end{array}$ & & Cognitive \\
\hline 8 & Indirect teaching of concepts of lesson & \multirow{8}{*}{$\begin{array}{c}\text { Method of } \\
\text { teaching } \\
\text { (codes } 8 \text { to 15) }\end{array}$} & environment \\
\hline 9 & Active learning of students & & \\
\hline 10 & Cultivation of thinking ability of learner & & \\
\hline 11 & Stimulation of inquisitiveness of students & & \\
\hline 12 & Without domineering and rigid behavior of educator & & \\
\hline 13 & Moderation in assigning home works & & \\
\hline 14 & Answerability of ambiguities and uncertainties of learner & & \\
\hline 15 & $\begin{array}{l}\text { Application of language and literature peculiar to children } \\
\text { in teaching }\end{array}$ & & \\
\hline 16 & Attention to individual differences of students in evaluation & \multirow{5}{*}{$\begin{array}{c}\text { Evaluation } \\
\text { procedure } \\
\text { (codes } 16 \text { to 20) }\end{array}$} & \\
\hline 17 & Evaluation according to persistent activities of students & & \\
\hline 18 & $\begin{array}{l}\text { Application of a variety of evaluation congruent with } \\
\text { subject }\end{array}$ & & \\
\hline 19 & Application of evaluation as a tool and not as a goal & & \\
\hline 20 & $\begin{array}{l}\text { Decrease of importance of grade in evaluating achievement } \\
\text { of goals }\end{array}$ & & \\
\hline
\end{tabular}

According to results inserted in table 6 , the concept of "communication between teacher and student " was obtained as a result of merging the codes 1 to 7 , the concept of "communication of students with together "was obtained as a result of merging codes in rows 8-11 and the concept of "communication of school personnel with students was obtained as a result of merging codes 12-14.This three concepts with together formed "social environment "category or environment as one of the effective elements of hidden curriculum on achieving the goals of religious education at schools.

The findings of the research about identifying the social environment as one of the effective elements of hidden curriculum at elementary schools are similar to the findings of pundits such as Borg (2002), Hebert (2000), Myles and Andreon (2001), Margolis (2002), Cannely (2008), and Chikeung (2008) that have concentrated on the social dimension of hidden curriculum. In their opinion, hidden curriculum includes those ideas, beliefs and insights that students obtain passively, directly from environment and in their relations with other students, teachers and school authorities and generally from the atmosphere of their own school.

In this regard, Portly (1993) believes that, in fact, in an invisible school, children of a country receive information through communication with each other and are exposed to special education that is usually programed and not predetermined.

Table 6. Extractive structure information of social environment category of hidden curriculum

\begin{tabular}{|c|c|c|c|}
\hline Row & Joint code & concepts & Category \\
\hline 1 & $\begin{array}{c}\text { Amity and intimacy of teacher with } \\
\text { students }\end{array}$ & \multirow{7}{*}{$\begin{array}{c}\text { Communication } \\
\text { (Relationship between teacher and } \\
\text { students) (Codes } 1 \text { to } 7)\end{array}$} & \multirow{9}{*}{$\begin{array}{c}\text { Social } \\
\text { environment }\end{array}$} \\
\hline 2 & Teacher respect for self-esteem of learner & & \\
\hline 3 & $\begin{array}{c}\text { No discrimination of teacher among } \\
\text { students }\end{array}$ & & \\
\hline 4 & Mutual respect of student for teacher & & \\
\hline 5 & Student trust in teacher & & \\
\hline 6 & $\begin{array}{c}\text { Teacher attention to language diversity of } \\
\text { students }\end{array}$ & & \\
\hline 7 & $\begin{array}{l}\text { Teacher attention to cultural diversity of } \\
\text { students }\end{array}$ & & \\
\hline 8 & Moral impacts of students on each other & Communication of students with each & \\
\hline 9 & Students impacts on belief of each other & other & \\
\hline
\end{tabular}




\begin{tabular}{|c|c|c|}
\hline 10 & $\begin{array}{c}\text { Cultural impacts of students on each other } \\
\text { Educational impacts of students on each } \\
\text { other }\end{array}$ & (Codes 8 to 11$)$ \\
\hline 12 & $\begin{array}{c}\text { Manner of personnel at school } \\
\text { environment }\end{array}$ & \\
\hline 13 & $\begin{array}{l}\text { Tone and oral literature of school } \\
\text { personnel }\end{array}$ & $\begin{array}{l}\text { Communication of school personnel } \\
\text { with students(Codes } 12 \text { to } 14)\end{array}$ \\
\hline 14 & $\begin{array}{l}\text { Extent of beliefs and Compliance of } \\
\text { personnel with religious commands }\end{array}$ & \\
\hline
\end{tabular}

According to results inserted in table 7, the concept of "school building" was obtained as a result of merging codes in rows 1 to 3 , the concept of "public and technical equipment of school "was obtained as a result of merging codes in rows 4-14 and the concept of "space and design of class was obtained as a result of merging codes 12-18. This three concepts together formed "physical environment "category or element as one of effective elements of hidden curriculum on achieving the goals of religious education at grade schools.

The findings of the research about physical environment as one of the effective elements of hidden curriculum of schools are similar to the findings of Weber (2009), Brandapaul (1997),Ferriter (2000) that have concentrated on the physical dimension of hidden curriculum. In their opinion, physical environment features of school, the equipment and tools that are used, all will affect the motivation, sentiments and presumptions of students. Weber and Ferriter, in their own research, investigated the effects of physical environment of school on the educational success of students, they, in their own studies, concluded that quite beautiful, decorated and bright class rooms with decent physical equipment for teaching the lessons are among the effective elements on educational success and advancement of students (Bayanfar and colleagues, 2010). In this regard Getzles (1974) has described the physical environment of classroom in various kinds of schools, and believes that each structure inspire children mind with a particular assumption of ideal student. According to Deutsch (Deutsch, 2004), style of school building and setting of class room can also contain implied messages.

Table 7. Extractive structure information of physical environment category of hidden curriculum

\begin{tabular}{clc}
\hline Row & \multicolumn{1}{c}{ Joint code } & Concepts \\
\hline 1 & School building agedness & Category \\
2 & Dimensions of school building & Bulding of school \\
3 & School construction plan and design & \\
\hline 4 & Library of school, kind and amount of books & \\
5 & School equipping with computer network & \\
6 & Amount and kind of school laboratories & Public and technical capabilities \\
7 & Prayer room of school and its design and & of school \\
& capacity & \\
8 & Degree of cleanness and health of school & \\
9 & environment & \\
10 & Amount and quality of sanitary services & \\
11 & Sufficient space for play and sport & \\
12 & Drinking fountain and refining system of & \\
13 & Amount of classes & \\
14 & Capacity of each class & \\
15 & Kind and setting of chair in class rooms & \\
16 & Light and illumination of classes & \\
17 & Heating and cooling system of classes & (codes 12 to 18) \\
18 & Educational complementary capabilities of & \\
& classes & \\
& &
\end{tabular}

According to results inserted in table 8 , the concept of "style of management and leadership" was obtained as a 
result of merging codes in rows 1 to 5 , the concept of" collection of rules and regulations of school" was obtained as a result of merging codes in rows 6-13 and the concept of "way of programing and sorting" was obtained as a result of merging codes 14-16.These three concepts together formed " administrative environment" category or element as one of the effective elements of hidden curriculum on achieving the goals of religious education at grade schools.

The findings of the research about identifying the administrative environment as one of the effective elements of hidden curriculum at schools are similar to the stand point of (Bergman and Gustan (1987) that believe hidden curriculum includes things that are found explicitly in principles and organization of education system(for instance, order and regularity at class and group state) and in pattern of relationship and communication in education centers(for instance, repeating the lessons, hearing ,complying,...).

In this regard, Townsend(Townsend,1995) also believes that some of components of educational environment lead to a kind of hidden educational curriculum that teachers teach it unintentionally and learners learn it unknowingly. This components include social structure of class room, way of using authority by teachers, rules dominant in relations of teacher-learner, standard learning activities, structural obstacles inside institution.

Table 8. Extractive structure information of administrative environment category of hidden curriculum

\begin{tabular}{|c|c|c|c|}
\hline Row & $\begin{array}{l}\text { Joint code } \\
\end{array}$ & Concepts & Category \\
\hline 1 & Extent of consultant of principal with teachers & \multirow{5}{*}{$\begin{array}{c}\text { Style of management and } \\
\text { leadership } \\
\text { (codes } 1 \text { to } 5)\end{array}$} & \multirow{16}{*}{$\begin{array}{l}\text { administrative } \\
\text { environment }\end{array}$} \\
\hline 2 & $\begin{array}{l}\text { Extent of principal intellectual agreement with } \\
\text { students parents }\end{array}$ & & \\
\hline 3 & Extent of principal criticism taking and patience & & \\
\hline 4 & $\begin{array}{l}\text { Possibility of students easy communication with } \\
\text { principal }\end{array}$ & & \\
\hline 5 & $\begin{array}{l}\text { Ways of encouragement and punishment at } \\
\text { school }\end{array}$ & & \\
\hline 6 & $\begin{array}{l}\text { Attention to psychological principles in } \\
\text { compiling the school regulations }\end{array}$ & \multirow{8}{*}{$\begin{array}{l}\text { Collection of rules and } \\
\text { regulations of school } \\
\text { (Codes } 6 \text { to 13) }\end{array}$} & \\
\hline 7 & $\begin{array}{l}\text { Possibility of changing or amending the school } \\
\text { regulations }\end{array}$ & & \\
\hline 8 & $\begin{array}{l}\text { Extent of students familiarity with school } \\
\text { regulations }\end{array}$ & & \\
\hline 9 & Discrimination in exerting the regulations & & \\
\hline 10 & $\begin{array}{l}\text { Extent of teachers compliance with administrative } \\
\text { order and regulations }\end{array}$ & & \\
\hline 11 & $\begin{array}{l}\text { Extent of teachers compliance with administrative } \\
\text { order and regulations }\end{array}$ & & \\
\hline 12 & $\begin{array}{l}\text { Extent of personnel compliance with } \\
\text { administrative order and regulations }\end{array}$ & & \\
\hline 13 & Extent of students compliance with regulations & & \\
\hline 14 & $\begin{array}{l}\text { Possibility of students contribution toward } \\
\text { programing the classes }\end{array}$ & \multirow{3}{*}{$\begin{array}{l}\text { Way of programing and } \\
\text { sorting } \\
\text { (Codes } 14 \text { to } 16)\end{array}$} & \\
\hline 15 & $\begin{array}{l}\text { Possibility of students contribution toward } \\
\text { arranging the schedule of examinations }\end{array}$ & & \\
\hline 16 & $\begin{array}{l}\text { Attention to students stand points toward sorting } \\
\text { the class }\end{array}$ & & \\
\hline
\end{tabular}

According to results inserted in table 9, the concept of "space and position of religious activities, was obtained as a result of merging codes in rows1 to 11, the concept of "divine- religious beliefs and faiths of students" was obtained as a result of merging codes in rows 12-15 and the concept of "extent of practical pledge of school personnel to religious obligations" was obtained as a result of merging codes 16-18. These three concepts together formed "religious environment "category or element as one of the effective elements of hidden curriculum on achieving goals of religious education at grade schools.

Findings of the research about identifying religious environment as one of the effective elements of hidden 
curriculum at schools are similar to the stand point of Michal Apple (1998) about hidden curriculum that he believes hidden curriculum is "implicit teaching of norms, values and making particular tendencies in learners. These findings are also similar to stand point of Mehr mohammadi (2008) that states hidden curriculum is suggesting learnings that learners experience in the framework of carrying out the explicit curriculum and because of attendance in the heart and context of dominant culture in education system.

Table 9. Extractive structure information of religious environment category of hidden curriculum

\begin{tabular}{|c|c|c|c|}
\hline Row & Joint code & Concepts & Category \\
\hline 1 & $\begin{array}{l}\text { School benefiting from religious-divine } \\
\text { books and films repository }\end{array}$ & \multirow{11}{*}{$\begin{array}{l}\text { Space and bases of religious } \\
\text { activity(codes } 1 \text { to } 11)\end{array}$} & \multirow{18}{*}{$\begin{array}{l}\text { Religious } \\
\text { environment }\end{array}$} \\
\hline 2 & $\begin{array}{l}\text { Extent of diversity and modernity of } \\
\text { religious-divine books and films repository }\end{array}$ & & \\
\hline 3 & $\begin{array}{l}\text { Quantity and quality of holding religious } \\
\text { celebrations and occasions }\end{array}$ & & \\
\hline 4 & $\begin{array}{l}\text { Holding religious educational courses in an } \\
\text { extracurricular manner }\end{array}$ & & \\
\hline 5 & $\begin{array}{l}\text { Content and extent of religious-cultural } \\
\text { camps and exhibitions }\end{array}$ & & \\
\hline 6 & $\begin{array}{l}\text { Amount and level of Quran memorization } \\
\text { and reading competitions at school }\end{array}$ & & \\
\hline 7 & $\begin{array}{l}\text { Amount of religious justifiable and popular } \\
\text { persons attending at school }\end{array}$ & & \\
\hline 8 & $\begin{array}{l}\text { Allocation of decent place for holding } \\
\text { religious customs }\end{array}$ & & \\
\hline 9 & $\begin{array}{l}\text { Extent of respect for religious-divine } \\
\text { multiplicity and diversity of students }\end{array}$ & & \\
\hline 10 & $\begin{array}{l}\text { Activities of school religious organizations } \\
\text { and groups }\end{array}$ & & \\
\hline 11 & Way of holding liturgical customs & & \\
\hline 12 & $\begin{array}{l}\text { Individual religious-divine beliefs and } \\
\text { faiths of students }\end{array}$ & \multirow{4}{*}{$\begin{array}{l}\text { Religious-divine beliefs and faiths of } \\
\text { students(codes } 12 \text { to } 15 \text { ) }\end{array}$} & \\
\hline 13 & $\begin{array}{l}\text { Family religious-divine beliefs and faiths } \\
\text { of students }\end{array}$ & & \\
\hline 14 & $\begin{array}{l}\text { Contradictions between religious beliefs of } \\
\text { student and content of lesson }\end{array}$ & & \\
\hline 15 & $\begin{array}{l}\text { Contradictions between religious beliefs of } \\
\text { student and teachers beliefs }\end{array}$ & & \\
\hline 16 & $\begin{array}{l}\text { Extent of school principal obligation to } \\
\text { religious commands and duties }\end{array}$ & \multirow{3}{*}{$\begin{array}{l}\text { Extent of school authorities obligation } \\
\text { to religious duties(codes } 16 \text { to } 18 \text { ) }\end{array}$} & \\
\hline 17 & $\begin{array}{l}\text { Extent of school teachers obligation to } \\
\text { religious commands and duties }\end{array}$ & & \\
\hline 18 & $\begin{array}{l}\text { Extend of school personnel obligation to } \\
\text { religious commands and duties }\end{array}$ & & \\
\hline
\end{tabular}

\section{Theory or Model}

5 variables were identified as variables of hidden curriculum according to the findings of the research (1Cognitive environment 2- Social environment 3- Physical environment 4-administrative environment 5- religious environment). Each of these hidden variables are defined by means of 3 observable variables that are formed according to placement of some joint codes in the form of one concept and have made the theory or model of the research that is presented in Figure 2. 


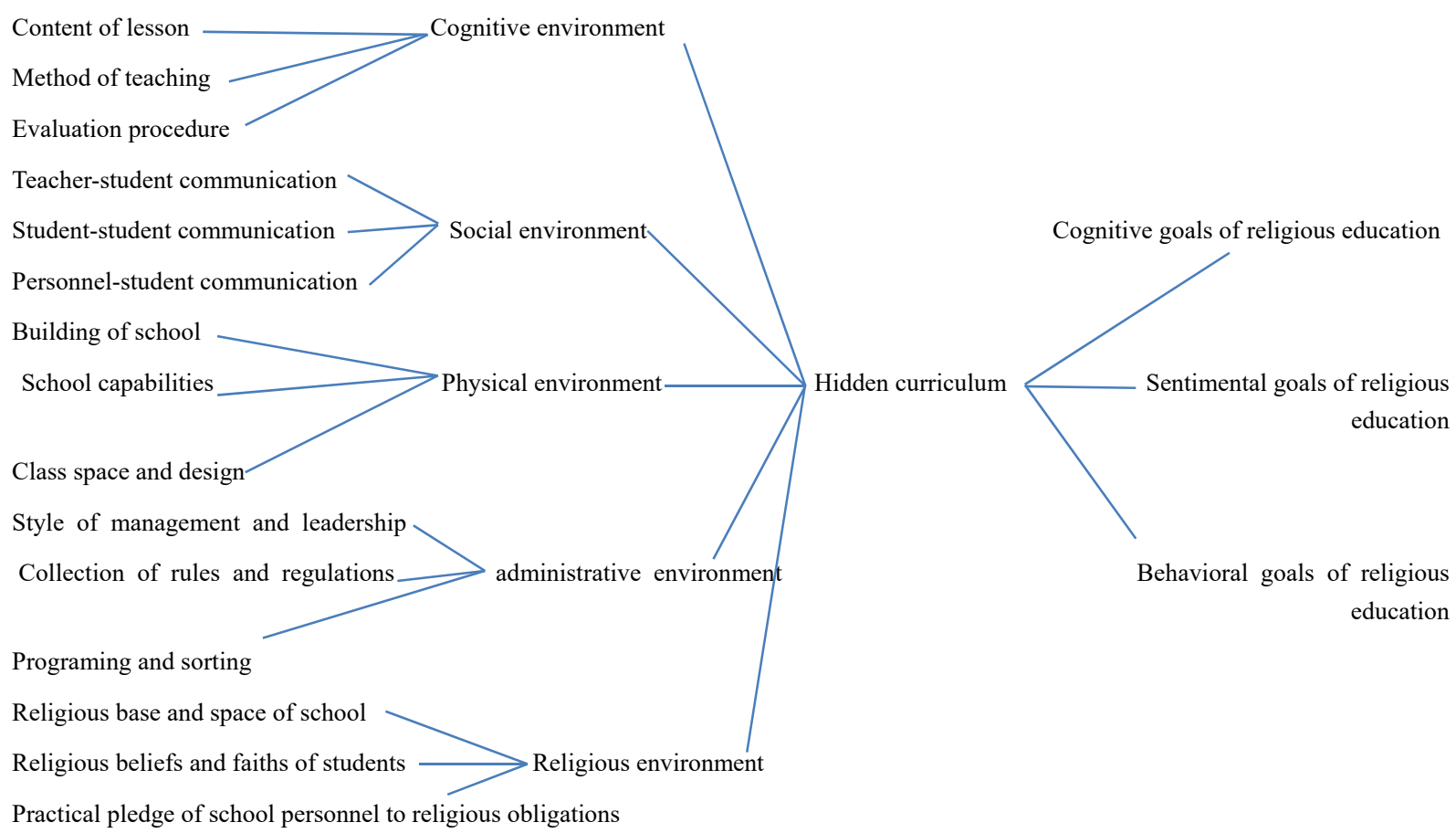

Figure 2. Theoretical model or research theory derived from analyzing the data

\section{References}

Apple, M. W. (2004). Ideology and Curriculum. New York: Routledge.

Ausbrooks, R. (2000). What is Schools hidden Curriculum teaching your child? Retrieved from http://www.parentigteens.com/curriculum.Shtm1

Bayanfar, F., Maleki, H., Delavar, A., \& Seif, A. (2011). Clarifying the effect of hidden curriculum of schools on the academic achievement students in middle school in order to provide a model. Journal of Educational innovations, 37, 71-100. Retrieved from http://fa.journal.sid.ir/searchpaper.aspx?journal $=\&$ subject $=\&$ writer $=111651$ \&year $=\& \mathrm{PDF}=\&$ Filter $=$

Bergenhennegouwen, G. (2009). Hidden Curriculum in the University. Retrieved from http://www.sociologyindex.com

Chikeung, C. (2008). The effect of shared decision - making on the improvement in teacher's Job development. Retrieved from http://www.eric.ed.gov

Dickerson, L. (2007). A postmodern view of the hidden curriculum. Jack N. Averitt College of Graduate studies.

Dixie, G. (2003). The importance of the physical environment. Retrieved from http://books.google.com

Doganay, A. (2009). Hidden curriculum on gaining the value of respect for human dignity. A qualitative study in two elementary schools in Adana. Retrieved from http://www. Educationalsciencestheory\&practice.com

Dreeben, R. (1967). On what is learned in school? London: Addison-Wesley.

Fallah, V., Barimani, A., \& Niyazazar, K. (2012). Investigating the role of hidden curriculum on student learning in secondary schools. Journal of management, 9, 45-51. Retrieved from http://fa.journals.ir/SearuchPaper.aapx ?journal $=\&$ subject $=\&$ writer $=106584 \&$ year $=\& P D F=\& F i l t e r$

Ferriter, B. (2009). Cell phones art disrupting the learning environment. Retrieved from http://teacherleaders.typepad.com

Fizroy community school (2007). Retrieved from http://www.fcs,vie,edu.au/artides.asp

Gabergolia, C. L., \& Gobble, M. E. (2012). A national perspective on teacher's efficacy in deaf education. Journal of Deaf Studies and Deaf Education, 17(3), 367-383.

Giroux, H. A. (2001). Theory and Resistance in Education. London: Bergin \&Garvey

Guskey, T. R. (2012). The influence of change in instructional effectiveness upon the affective characteristics of 
teachers. American Educational Research Journal, 17, 367-383.

Jackson, P. W. (1968). Life in Classrooms. New York: Holt, Reinhart \& Winston.

Kentli, F. D. (2009). Comparison of Hidden Curriculum Theories. Ozean Publication.

Konieczka, J. (2013).The Hidden Curriculum. Advanced Research in Scientific Areas, 2-6.

Margolis, E. (2000). Class pictures: representations of race, gender and ability in a century of school photography. Educational policy analysis archives, 8 (31).

Margolis, E. (2001). The hidden curriculum in higher education. Retrieved from http:// books.google.com

Myles, B.S., \& Andreon, D. (2001). Asperger syndrome and adolescence: practicul solutions for school success Shawnee mission ,ks .autismasperger publishing co.

Redish, E. F. (2009). The hidden curriculum: what do we really want our students to learn? Retrieved from http://www.sociologyindex.com

Shurifah, T. S. A. (2010). The other curriculum in pesantren exploring possible triggers ofradicAlisva. Retrieved from http://www.pvtr.org/pdf

Smith, A., \& Montgomery, A. (2008). Values and hidden curriculum. Retrieved from http://www. Cainweb.Service

Stephen, S. A. M. (2009). Skirmishes on the border: How children experienced, influenced and enacted the boundaries of curriculum in an early childhood education. Retrieved from http://reseurchive.vum.ac.riz

Weber, S. (2009). Curriculum development: Apolitical act. Retrieved from http:// www.k12curriculumdevelopment.com

\section{Copyrights}

Copyright for this article is retained by the author(s), with first publication rights granted to the journal.

This is an open-access article distributed under the terms and conditions of the Creative Commons Attribution license (http://creativecommons.org/licenses/by/4.0/). 